\title{
THE IMPLEMENTATION OF ANTI-TRUST LEGISLATION IN AN ECONOMY UNDERGOING TRANSFORMATION, USING THE EXAMPLE OF THE POLISH TABLOID MARKET
}

\author{
Hanna Trojanowska \\ Siedlce University, Poland
}

\begin{abstract}
The problem of predatory pricing and legislation on it is a long-established feature of western market economies, but for Poland and other post-communist countries, it is a relatively new phenomenon. One aspect of the transformation to a market economy in Poland was the introduction of anti-trust legislation, the implementation of which has often posed a dilemma for the courts: to strictly enforce laws forbidding predatory pricing, or to err on the side of leniency, in order to encourage competition. This article examines these issues in the context of the court case involving two Polish tabloid newspapers, 'Super Express' and 'Fakt', and the long-term impact of the court's verdict.
\end{abstract}

Keywords: predatory pricing, market theory, game theory, Chicago School, Polish press market

DOI: http://dx.doi.org/10.15549/jeecar.v1i2.54

\section{INTRODUCTION}

As a result of the political changes of 1989, Poland adopted the western economic model, and its leaders set about transforming its centrally planned economy to one based on capitalism. During the communist era, the economy had been based almost entirely on state-owned companies, each of which generally had a monopoly in its particular branch. Therefore, in order to achieve the goal of transformation to a market economy in the western style, all of these monopolies had to be broken by the introduction of competing companies into the various branches of the economy.

However, carrying out this process of transformation of the economy was by no means a simple task, not only because of obstacles such as social costs or the absence of appropriate legislation. It soon became clear that, in many areas, a simple transfer of western system solutions could have the opposite effect to what was intended.

One example of the complexities involved in the transformation process is the attempt to apply western standards to companies wishing to gain dominance in particular branches of the Polish economy through the use of limit pricing and predatory pricing strategies (Milgrom, Roberts, 1982,a). Both of these strategies are designed to achieve (Milgrom, Roberts, 1982,b) or maintain a dominant position by eliminating rivals. This, of course, is the essence of market competition, but in order for the market to work efficiently and for the ultimate benefit of society, such elimination of competitors should always be associated with some form of advantage such as, for example, lower production costs. In 1989, one of the best examples of an efficiently working market economy appeared to be the American one. So the policymakers charged with transforming Poland's economy were faced with the problem of how to apply "healthy" market competition rules which would facilitate free enterprise at the same time as ensuring, as far as possible, a "level playing field".

A crucial question was the extent to which the use of limit pricing and predatory pricing strategies should or could be penalized (McGee, 1958). These strategies, which involve a company attempting to gain market advantage by manipulating prices, or merely using the threat of this manipulation, in order to oust competitors from the market, clearly run counter to the above-mentioned rules of the "healthy" market economy. Similar practices are considered illegal in the U.S. (Areeda, Turner, 1975)

Now, more than twenty years after the beginning of the process of transformation, the present situation in Poland can clearly be seen to have been brought about partly as a result of the previous decisions concerning market structure made by the Polish authorities, and as such, is of great relevance to other countries undergoing comparable transformations. In the era of globalization, it is crucial to be aware that economic rules formulated in the west, with the ostensible purpose of upholding "healthy" principles, cannot be applied automatically. Policymakers have to discuss the real impact of their decisions on the economy and consider what is more important: the rules themselves or their effects. Otherwise, the usage of "western" rules will not necessarily lead to the development of economies based on the "western" model.

In this article, we will use the Polish tabloid press market as an illustration of the fact that, paradoxically, an action that could be classified as a predatory pricing strategy can, in reality, contribute to the development of the branch, breaking a monopoly and introducing competition on a commercial basis.

Firstly, we will give a general view of the problem from the practical point of view, describing the situation on 
the Polish tabloid market. This will conform to the latest trends in academic writing in emphasizing that the choices made by homo economics have two aspects: social and economic. Then the theoretical basis of the problem will be presented, both from the economic point of view, and in terms of the legal acts that have influenced the structure of the market. This will be followed by a discussion where we will consider the present effect of past decisions, and examine whether they have contributed to achieving the goal of the transformation of a Polish economy based on communistic ideology into one functioning along "western" lines. Finally, we will formulate our conclusions.

\section{An overview of the Polish press market}

Prior to the changes in 1989, although Polish newspapers were a propaganda tool in the hands of the Communists, magazines devoted to culture represented a high level both in terms of style of expression, as well as the substantive content. The Poles had great respect for the printed word and had high demands on its intellectual level.

After 1989, along with western economic ideas, Polish versions of western press titles arrived in Poland, mainly in the form of the so-called women's press. New Polish newspapers were also founded in these years, among them the opinion-forming "Gazeta Wyborcza" and the first Polish tabloid, "Super Express".

Despite opening up to Western standards in economics and culture, Polish readers still had high expectations towards the press, which therefore tended to avoid "low" topics. So from its inception in 1991, "Super Express" was marketed as something that was more than just a tabloid, and differed from western-style tabloid newspapers. This created an interesting gap in the market from the point of view of foreign investors.

In October 2003 the first issue of "Fakt" - the Polish version of the German tabloid "Bild" - was sold. The front page featured a large photograph of the face of an evidently impoverished woman together with the headline "I have to die, because I am poor." In the corner, in the background was a naked picture of a well-known Polish sportsman and his wife. This blatant juxtaposition of poverty and opulence introduced Polish readers to a previously unknown way of evoking emotions. However, despite the passage of 14 years since the opening of the west, Poles in general were not yet prepared for such a form of communication, and "Fakt", with all its sensationalism, was not an immediate success.

Within a month, though, sales began to increase significantly. The reason was Fakt's introduction of Poland's first nationwide newspaper competition with prizes. Many new readers were attracted by the very large number and quality of prizes. This allowed the proprietors of "Fakt" to better identify the needs of consumers and refine the product. By December 2003, it was a sales leader, and by February 2004, it had a larger readership than any other Polish newspaper and was attracting $12 \%$ of new consumers who had not yet read the press. At the time of its launch, the sales target was 200-300 thousand copies. In February 2004 , sales totaled 1,000,000.

What was evident, however, was that on the Polish market specific price was not the most important element of success. This was demonstrated in the early days of Fakt's existence, when sales were significantly below the set threshold of 200,000 .

\section{The theory and practice of predatory pricing laws in the US}

Until the mid- twentieth century the problem of predatory pricing had not been discussed in scientific papers. The first approach to the problem was done by McGee in 1958 (McGee, 1958). Prior to 1958, the courts relied on the concept of "general truth" that was not rooted in economic academic theory.

Talk about the predatory nature of the press was initially polemics. Before 1975Areeda Turner test (Areeda, Turner, 1975) judges were guided by the idea of protecting free competition, and very rarely referred to the views of economists (Elzinga, 1970). It was only with the formulation of the Areeda-Turner (Areeda,1975) test for predatory pricing that this situation began to change. The courts began to use these rules almost immediately after the publication of the article. However, disputes continue to this day, and the case law is often based on precedent, because despite the emergence of many scientific papers on the subject, it is still difficult to say what really constitutes irrefutable proof that a company actually tried to use an unfair strategy to eliminate competitors. The problem here is to prove the "intent" of the company. Such as in 1993, when the U.S. Supreme Court issued a verdict in the case of Brook Group Ltd v Brown \& Williamson Tobacco Corp., which did not discover any elements of predatory pricing strategy in the reduction rates (Arthur, 1996).

\section{The theoretical basis for the legal conditions}

According to Koller (Koller, 1971), in order to prove " intent " to use predatory pricing, it is necessary to check whether the alleged predator has set a price below the level of its short-term average cost of production and that as a result of these actions a competitor has been eliminated from the market or absorbed by the alleged predator predation can not only be a way of discouraging competition from entering the market (Trojanowska, 2012).

For the Chicago School (McGee, 1958), a short-term price below average total cost can be a sign of "healthy " competition. Furthermore, there is nothing wrong in their view with a company intending to eliminate rivals from the market, since they believe that all commercial activity has the aim of overcoming or eliminating competition. Moreover, the authors of many articles are skeptical of the possibility of obtaining secure and reliable data on the average cost structure of a company (McGee, 1958).

Areda and Turner formulated a test consisting of a series of steps which should be followed by a judge hearing a predatory pricing case, in order to ensure that the judgment is fair. They acknowledge that it is difficult to determine whether an attempt to use predatory pricing actually took place, but they have no doubt that such an action would be illegal, and that any reduction in prices below average variable costs, which was aimed at eliminating rivals, should meet with restrictions on the part 
of the authorities (Areeda, 1975).

Williamson (Williamson, 1968, 1977) is of a similar view, arguing that an increase in monopoly power gained by artificially lowering prices should be prohibited by law. Similarly, Baumol (Baumol 1982) contends that a predatory pricing strategy can only be successful if the company, after getting rid of the competition and obtaining the position of a monopoly, is able to increase prices. Milgrom and Roberts (Milgrom, Roberts, 1987), on the other hand, use game theory to prove that the use of a limit pricing strategy can lead to profits.

Posner (Posner, 1988) defines predatory pricing as pricing at a level that allows a company to eliminate from the market another company which is just as or more effective than the predator. In his view, this is possible only in two cases. Firstly, if the predator sets the price of the product below the short-term marginal cost. However, in such a situation it is very difficult to accurately assess whether we are actually dealing with predators, since similar activities take place in the case of e.g. sales promotions. Secondly, when, in order to eliminate competition, the price is set below the long-term marginal cost.

Lea (Trojanowska, 2005), however, takes issue with Posner's argument that the flexibility of the market and its unique properties prevent the existence of adaptation strategies such as predatory pricing. Lea insists that because of technological advances the world economy has changed, and predatory pricing is far more common than Posner believes. Williamson is also of the view that setting prices below marginal cost is not a good indicator of predatory pricing (Williamson 1968, 1977).

Joskow and Klevorick propose a two-step test: an analysis of the long-term impact on the market structure, followed by an analysis of costs and prices. The authors admit that there are no "ideal" rules that prevent companies from adapting to the provisions of the law so as, in fact, to circumvent them. In the case of costs, it is important to check whether they are genuine or inflated is only possible as a benchmark (Joskow, Klevorick, 1979).

\section{DISCUSSION}

The core of the problem of predatory pricing strategy applied in Poland is more complex than in the USA. A mature market reacts differently to the same stimuli than a market that is in the process of transformation. Is is very easy to explain such a phenomenon by the fact that one of the most important issues that forms the contemporary free market is information. Milgrom and Roberts distinguish three kinds of information, arguing that where only imperfect information is available, it is possible to apply a predatory pricing strategy.

But for the purpose of this article we have to understand the range of the word "information" in a much broader meaning. In an economy undergoing a very deep process of transformation, like Poland's after 1989, only a minority of society understood the mechanism of the "new order". This is why the market reaction to various stimuli is so unpredictable. An illustration of this is the fact that the vast majority of Polish society just after 1989 treated all $\mathrm{TV}$, press or radio commercials as reliable sources of information. People were not aware of the specific traits of commercials and their role in the whole process of sales and marketing. So the same message broadcasted in the USA would have had a different or even opposite meaning in Poland, and a firm's signaling its strength by lowering the price of its product under the level of that of its competitor, which is the core of predatory pricing strategy, might have had a different impact on the market.

In general, the main negative impact of predatory pricing strategy on the market structure is that it may lead to monopolization through unfair practice. And this would be against the most important principle of a free market, that its structure should be formulated by the interaction of many participants in the market rather than a single monopolist. In theory, the main beneficiary of a free market structure is the consumer: the more participants there are in the market, the lower the prices are, and the more goods they offer to sell.

In a mature market economy like that of the USA, consumer welfare and its protection it by law has always been an important element of the political system. In postcommunist Poland, these terms were new for society. Many economists thought that a simple transfer of western patterns would be sufficient for a successful transformation from communism to a market economy. But we argue that it was not.

With the new system, Poland faced not only a new order, but also problems that could not simply be solved by implementing e.g. US law. Poland's transformation also needed a new approach towards the problem of predatory pricing.

It is important to remember that the two most important factors in deciding whether a predatory pricing strategy was applied are the intention of using the strategy and a short-term lowering of price under cost level, where the potential loss should be recouped in the long-term perspective.

In the above-mentioned situation on the Polish press market, the introduction of "Fakt" had all the symptoms of a predatory pricing strategy. Firstly, the price of $1 \mathrm{zł}$ was undoubtedly below any possible price that would cover the cost of production. Secondly, it seemed highly likely that the loss caused by the artificially low prices would be recouped in the long term. Press is a specific product and the potential income comes not only from selling the product but also from the potential readership. And this has a very strong influence on advertising. Advertisers make a decision on what newspaper to choose for their product on the basis of how much it costs to reach one reader. The lower the price is, the greater the readership it attracts, and hence the lower the cost of reaching out to one customer for the advertiser. So not only could a predator's lowering its prices cause damage to its competitors, but there is clear potential for its short-term losses to be recouped in the form of income from advertisements.

This was clearly the case with "Fakt", and moreover the intention to use a predatory pricing strategy was obvious. Not only was the price was artificially low, but also Axel Springer launched a new journal "Dziennik", which would compete with other segments of the press market. 
"Super Express" finally initiated legal proceedings against "Fakt". The court, however, did not find in favor of "Super Express", justifying its verdict with the general message that the Polish market was not sufficiently stable to make it reasonable to punish "Fakt". This verdict might seem surprising to academics and legislators concerned with the problem of predatory pricing, since all the actions undertaken by "Fakt" were the same as in a typical model of a predatory pricing strategy.

But the court emphasized the fact that Poland was facing very deep changes to its political system. It had to decide whether to judge the situation as if it had arisen in a mature system, or to focus on the problem of transforming the economy into a competitive form. Ultimately, it decided on the latter.

After 10 years, it is possible to have another perspective and judge the problem from a third point of view. The verdict in the US case involving Matsushita and Zenith (Matsushita, 1348) provided another indicator time. The US court based its verdict on the fact that both competitors stayed on the market and did not go bankrupt. We can take the same approach in commenting on the "Super Express" v "Fakt" case. Today, both firms are still in operation and the Polish press market can be regarded as competitive, so it is clear that the court's decision to prioritize the transformation of the economy over the strict application of predatory pricing laws has proved to be the right one.

\section{CONCLUSIONS}

Since 1989, the Polish economy has been in the process of transformation from a centrally planned to a market economy. In the first decade, the process was more intense and dramatic, but changes are still being made, as Poland attempts to adjust its economy to the level of other economies in the European Union.

Economies that are undergoing a process of transformation are operating in specific circumstances. This is why in the legal system and its execution in the courts, it is necessary to give sufficient consideration to the question of what should be regarded as most important in any legal action. Simple adherence to the letter of the law or other rules might not be consistent with what should be the overriding goals of commercial legislation, namely the democratization of the system and the transformation to a market-oriented economy. The verdict in the case of "Super Express" v "Fakt", and the continuing presence of both these tabloids on the Polish press market provides an excellent illustration of the appropriateness of "taking a wider view" in such cases.

This experience might be very informative for other economies of Central European region. Simple implementation of western patterns does not always lead to the democratization and commercialization of the economy towards a competitive market, which should be the priority for lawmakers in the era of transformation.

\section{REFERENCES}

Areeda, P., Turner, D. (1975). Predatory Pricing and Related Practices Under Section 2 of the Sherman Act, Harvard
Law Review, No 88, 697-733.

Areeda P., Turner, D. (1976). Scherer on Predatory Pricing: A Reply, Harvard Law Review, No 89, 891-900.

Areeda P., Turner, D. (1978). Williamson on Predatory Pricing, Yale Law Journal 87, Iss. 7 (June), 1337.

Arthur, B. (1996). Increasing Returns and the New World of Business, Harvard Business Review (July-August).

Auerbach, S. (1987). Japanese Companies Violated Trade Laws, Washington Post (November 20).

Baumol, W. (1982). Contestable Markets: An Uprising in the Theory of Industry Structure, The American Economic Review, Vol. 72, No 1 (March), 1-15.

Baumol, W. (1986). Microtheory. Applications and origins, Simon \& Schuster International Group, Cambridge.

Baumol, W., Panzar, J., Willing, R. (1982). Contestable Markets and The Theory of Industry Structure, Harcourt Brace Jovanovich, San Diego.

Elzinga, K. (1970). Predatory Pricing: The Case of the Gunpowder Trust, Journal of Law and Economics, No 13 (April), 223.

Kamp, B. (1997). Faux Predation in Markets with Imperfect Information on Product Quality, Southern Economic Journal, No 64, 2 (October), 555-566.

Koller, R. (1971). The Myth of Predatory Pricing: An Empirical Study, Antitrust Law and Economics Review, No 4 (Summer), 110.

Koller, R. (1979). When is Pricing Predatory, Antitrust Bulletin, No 24 (Summer), 283.

Kreps, D. (1993). Game Theory and Economic Modelling, Oxford University Press, Oxford.

Kreps, D., Milgrom, P., Roberts, J., Wilson, R. (1982). Rational Cooperation in the Finitely Repeated Prisoners' Dilemma, Journal of Economic Theory, No 27, 245-252.

Kreps, D., Wilson, R. (1982). Reputation and Imperfect Information, Journal of Economic Theory, No 27, 253279.

Joskow, P., Klevorick, A. (1979). A Framework for Analyzing Predatory Pricing Policy, The Yale Law Journal, Vol. 89, No 2 (December).

Lachica, E., White, J. (1991). Washington is Expected to Investigate Alleged Dumping of Japanese Minivans, Wall Street Journal, June 20, p. B3.

Lea, G. (2005). What the heck is...Chicago School, from www.theregister.co.uk

Matsushita Electric Industrial Co. v. Zenith Radio Corp. 106. S. Ct 1348.

McGee, J. (1958). Predatory Price Cutting: The Standard Oil (N.J.) Case, Journal of Law and Economics, No 1 (April), 137-169.

McGee, J. (1980). Predatory pricing Revised, The Journal of Law and Economics, No 23, 289-330.

Milgrom, P., Roberts, J. (1982). Limit Pricing and Entry Under Incomplete Information: an Equilibrium Analysis, Econometrica, Vol. 50, No. 2 (March), 443459.

Milgrom, P., Roberts, J. (1982). Predation, Reputation and Entry Deterrence, Journal of Economic Theory, No 27 (August), 280-312.

Milgrom, P., Roberts, J. (1987). Informational Asymmetries, Strategic Behaviour, and Industrial Organization, The American Economic Review, Vol. 77, No. 2 (May), 184193.

Miller, J., Paulter, P. (1985). Predation: The Changing View in Economics and the Law, Journal of Lawand Economics, No 28 (May), 495.

Posner, R. (1988). The Social Costs of Monopoly and 
Regulation, in: Stigler, G. (ed) Chicago Studies in Political Economy, The University of Chicago Press, Chicago.

Posner, R. (1992). The Antitrust Laws, in: Economic Analysis of Law, Little, Brown and Company, Boston.

Selten, R. (1975). Reexamination of the Perfectness Concept for Equilibrium Points in Extensive Games, International Journal of Game Theory, No 4: 25-55.

Selten, R. (1978). The Chain Store Paradox, Theory and Decision, No 9, 127-59.

Baumol, W. (1979). Quasi-Permanence of Price Reductions: A Policy form Prevention of Predatory Pricing, Yale Law Journal, No 89, 1-26.

Trojanowska, H. (2005). Strategia cen drapieżnych-teoria a praktyka, Zeszyty Naukowe SGH, Kolegium Gospodarki Światowej, No 18.

Trojanowska, H. (2012). The Entrant as Predator-a New Approach Towards Predatory Pricing, in: Research in Management and Business in the Light of Practical Needs, University of Presov, Slovakia.

Williamson, O. (1968). Wage Rates as a Barrier to Entry: The Pennington Case in Perspective, The Quarterly Journal of Economics, Vol. 82, No. 1 (Feb.), 85-116.

Williamson, O. (1977). Predatory Pricing: A Strategic and Welfare Analysis, Yale Law Journal, No 87, 284-340.

\section{ABOUT THE AUTHOR}

Hanna Trojanowska, email: hannamagdalena@wp.pl

Dr. Hanna Trojanowska is an assistant professor in the Law and Economics Faculty at Siedlce University in Poland. The main areas of her research are predatory pricing, limit pricing, game theory, the philosophy of language in economics, and the history of economic thought. She obtained her doctorate from the Warsaw School of Economics, and has published several papers on predatory pricing, limit pricing, and the current economic crisis, as well as contributing to Gale's Encyclopedias of Marketing and Emerging Markets. She has been a reviewer at many international conferences and is on the reviewer/editorial board of the Journal of Eastern European and Central Asian Research. 